\title{
DIPLOMASI PUBLIK INDONESIA MELALUI BALI DEMOCRACY FORUM
}

\author{
Yuswari O. Djemat ${ }^{1}$ \\ 1Program Studi Ilmu Hubungan Internasional, Fakultas Ilmu Sosial \& Ilmu \\ Politik, Universitas Jenderal Achmad Yani
}

\begin{abstract}
Public Diplomacy for a country is an important tool. This study aims to analyze the public diplomacy strategy carried out by Indonesia as a response to the Global War on Terror (GWOT) policy carried out by America after the events of September 1 1, 2001. Public diplomacy carried out by Indonesia through the Bali Democracy Forum (BDF) is growing. Every year the number of participating countries participating in the BDF continues to increase. Indonesia must be able to take advantage of this momentum and formulate an increasingly comprehensive public diplomacy strategy in order to improve Indonesia's selfimage in the eyes of the international community. This study uses qualitative research methods with descriptive research types and secondary data collection through literature studies, such as books, journals, e-books, $e$ journals, and other internet sources such as from government agencies, ministries, embassies of the Republic of Indonesia (RI) and portals. online news.
\end{abstract}

Keywords: Public Diplomacy, Nation Branding, Democracy, Democratization.

\section{PENDAHULUAN}

Peristiwa 9/11 yang terjadi di Amerika Serikat pada tahun 2001 telah mengubah tatanan politik dunia. Peristiwa yang dikenal dengan nama the Black September ini memakan jumlah korban materi dan immaterial yang sangat besar dan membawa konsekuensi besar bagi negara-negara di dunia, termasuk Indonesia. Dunia dibuat terkejut dengan peristiwa penabrakan gedung World Trade Center 4 di New York oleh lima teroris Al-Qaeda yang membajak sebuah pesawat terbang American Airlines Boeing 767-223ER dengan rute Boston-Los Angeles pada pukul 08:46 waktu setempat. Amerika Serikat sendiri juga terkejut dengan peristiwa tersebut yang menewaskan 92 penumpang, awak dan teroris di dalam pesawat dan ribuan orang lainnya. Amerika terkejut dan heran atas kebencian para teroris yang begitu mendalam terhadap Amerika Serikat.

Hasil kajian Vivien Walker, terdapat data bahwa $82 \%$ penduduk Palestina memiliki pandangan negatif terhadap Amerika Serikat, di Yordania 
terdapat 74\%, Mesir 70\%, Turki 69\%, dan Pakistan 68\%. Berdasar temuan Walker tersebut didapat kesimpulan bahwa banyak penduduk di negaranegara di luar Amerika Serikat yang tidak menyukai kebijakan Amerika Serikat (Vivien S. Walker, 2012). Peristiwa 9/11 membuat Amerika Serikat menjadikan keamanan nasionalnya sebagai fokus utama dan dimulailah wacana Global War on Terror (GWOT) yang dilakukan di bawah kepemimpinan Bush Jr. Amerika Serikat semakin intensif mengarahkan fokus kebijakan luar negerinya kepada negara-negara yang dianggap mempunyai potensi akan kemunculan kelompok-kelompok yang berseberangan dan memusuhi Amerika Serikat. Berdasar Laporan Komisi 911, Indonesia merupakan lingkaran kedua setelah negara-negara yang berada di Timur Tengah karena Indonesia merupakan negara dengan jumlah penduduk muslim terbesar di dunia.

Situasi politik internasional yang berubah sejak peristiwa 11 September 2001 tersebut, direspon oleh Indonesia dengan menyusun strategi diplomasi publik melalui upaya Indonesia memberikan citra diri sebagai sebuah negara demokratis. Salah satu strategi diplomasi publik Indonesia adalah dengan menyelenggarakan Bali Democracy Forum (BDF) Sejak 2008 pada masa pemerintahan Presiden Susilo Bambang Yudhoyono (SBY). Penyelenggaraan BDF juga mendapat respon yang positif dari berbagai negara. Hal ini terlihat dengan peningkatan jumlah peserta dan observer BDF. Pada awal penyelenggaraan BDF, jumlah peserta dan observer hanya terdapat 28 negara. Pada tahun 2013, jumlah peserta dan observer BDF meningkat menjadi 128 negara.

Penelitian ini menggunakan metode penelitian kualitatif dengan tipe penelitian deskriptif. Penelitian kualitatif memiliki ciri-ciri sebagai berikut (Moleong, 2007 : 8-13): Latar alamiah, manusia sebagai alat (instrumen), metode kualitatif, analisis data secara induktif, teori dan dasar (grounded theory), deskriptif, lebih mementingkan proses daripada hasil, adanya batas yang ditentukan oleh fokus, adanya kriteria khusus untuk keabsahan data, desain yang bersifat sementara, hasil penelitian dirundingkan dan disepakati bersama. 


\section{Diplomasi Publik}

Diplomasi publik adalah diplomasi yang dilakukan oleh sebuah negara dengan tujuan untuk mempengaruhi publik di luar negaranya, atau mempengaruhi negara lain dalam lingkup global untuk mencapai kepentingan nasional. Diplomasi publik dapat dilakukan dengan cara propaganda, nation branding dan mendorong pertukaran budaya. Diplomasi publik dipengaruhi oleh kondisi politik internasional, kondisi internal negara, dan isu-isu politik, baik dari dalam maupun luar negeri. Praktik diplomasi publik di Indonesia ditujukan kepada masyarakat internasional dan juga kawasan domestik.

Ada empat tujuan diplomasi publik di abad 21, yaitu: untuk meningkatkan hubungan yang akrab dan membuat publik di luar negaranya untuk berpikir dan dapat mengubah image/persepsi mereka tentang negara serta meningkatkan pengetahuan masyarakat mengenai negara tersebut; untuk memberikan persepsi yang positif dengan cara membuat publik melihat suatu dalam hubungan internasional dari perspektif negara tersebut; untuk merangkul publik mancanegara dan mendorong publik mancanegara untuk melihat suatu negara sebagai tujuan yang menarik bagi pariwisata dan studi, membeli barang barang, maupun mengadopsi nilai-nilai negara tersebut; dan untuk mempengaruhi sikap publik mancanegara dan meningkatkan dukungan masyarakat mancanegara terhadap posisi negara tersebut (Leonard, 2009:9).

Diplomasi publik secara tradisional berdasar kepada aktivitas resmi, seperti pertukaran budaya, seminar, promosi ekonomi, advokasi politik, dan lain sebagainya. Diplomasi publik memerlukan komunikasi dua arah untuk menciptakan komunikasi efektif. Hampir semua aktivitas disusun dan diatur oleh pemerintah. Namun sekarang, sebuah pemerintahan tidak bisa berdiri sendiri dalam menghadapi hubungan internasional yang semakin rumit. Mereka membutuhkan dukungan dari aktor yang lain yaitu aktor non negara. Diplomasi publik salah satu tujuan akhirnya adalah nation branding. Nationbranding memerlukan pendekatan yang menyeluruh/holistik, dimana hal tersebut akan sangat berpengaruh untuk membangun citra suatu negara, terutama kepada negara yang lemah (Melissen, 2005:20). 


\section{Demokrasi}

Demokrasi jika dilihat secara etimologis berasal dari kata demos yang berarti rakyat dan kratos yang berarti kekuasaan, yang secara sederhana dapat diartikan sebagai kedaulatan (pemerintahan) berasal dari rakyat, dijalankan oleh rakyat dan untuk rakyat. Demokrasi berasal dari pemikiran Yunani, di mana rakyat sendiri memiliki dan menjalankan kekuasaan politik (Esposito, 1986:12). Sidney Hook berpendapat bahwa demokrasi merupakan bentuk pemerintahan di mana kebijakan-kebijakan pemerintah yang krusial secara langsung atau tidak langsung berdasarkan kepada kesepakatan mayoritas dari rakyat (A Ubaedillah, dkk, 2006:130-131). Philippe C Schmitter dan Terry Lynn Karl mengatakan bahwa demokrasi adalah sebuah sistem pemerintahan dimana pertanggungjawaban akan dimintai kepada mereka yang terpilih.

\section{PEMBAHASAN}

\section{Praktik Demokrasi di Indonesia}

Demokratisasi di Indonesia dapat dilacak jejaknya terutama pada saat berakhirnya rezim Orde Baru (Orba) yang ditandai dengan lengser keprabonnya Presiden Soeharto pada 21 Mei 1998. Sejak itu terjadi reformasi di berbagai bidang di Indonesia, Indonesia memasuki era yang dikenal dengan nama era reformasi. Selama 32 tahun di bawah pemerintahan Presiden Soeharto Indonesia berada dalam suasana yang militeristik dan sentralistik, di mana pada era reformasi dimulailah demokratisasi di Indonesia. Salah satu hasil dari reformasi di Indonesia adalah dilakukannya desentralisasi dan otonomi daerah. Selain itu, dilakukan berbagai upaya supremasi hukum, pemberantasan korupsi kolusi dan nepotisme $(\mathrm{KKN})$, penghapusan dwi fungsi ABRI/TNI, masyarakat sipil diberikan kebebasan dan juga media massa, promosi dan kampanye perlindungan Hak Asasi Manusia (HAM) yang semakin diintensifkan, serta terselenggaranya Pemilihan Umum (Pemilu), di mana Presiden, Kepala Daerah dan Wakil Rakyat dipilih langsung oleh rakyat.

Demokratisasi di Indonesia terlihat juga dengan terjadinya desakralisasi lembaga kepresidenan. Pada masa Orba, presiden adalah 
penguasa tunggal dan tidak tersentuh oleh hukum. Akan tetapi, ketika reformasi terjadi, presiden dapat dilengserkan dari kekuasaannya. Hal lain yang dapat menjadi parameter keberhasilan demokratisasi di Indonesia adalah terselenggaranya lima kali pemilu, yaitu pemilu tahun 1999, 2004, 2009, 2014 dan 2019. Bagi praktik demokrasi dan demokratisasi di negara demokrasi, pelaksanaan pemilu merupakan momentum untuk mempertegas arah konsolidasi demokrasi dan penguatan kelembagaan politik. Melalui pelaksanaan pemilu di Indonesia itu, maka transisi demokrasi di Indonesia dapat berjalan sesuai rencana dan dapat mendorong Indonesia sebagai sebuah negara "South East Asia's only fully functioning Democracy" (Heru Nugroho, 2012:12). Proses demokrasi di Indonesia masih memiliki beberapa kekurangan diantaranya adalah sektor kehidupan masyarakat baik dalam bidang ekonomi, pendidikan, kesehatan, pengelolaan lingkungan hidup dan sebagainya, masih jauh dari apa yang dicita-citakan oleh masyarakat. Dapat dikatakan bahwa demokratisasi di Indonesia hanya sebatas meningkatkan kebebasan politik dan penghargaan atas hak asasi manusia, tetapi belum menerapkan demokrasi dalam pembangunan ekonomi dan memberdayakan ekonomi rakyat agar dapat menuntaskan kemiskinan.

\section{Pelaksanaan Bali Democracy Forum sebagai Forum Demokratisasi Global}

Bali Democracy Forum (BDF) merupakan forum atau pertemuan kerjasama negara-negara yang dilaksanakan setiap tahun pada setiap bulan Desember di Bali, Indonesia. Forum kerjasama BDF bertujuan untuk meningkatkan kapasitas demokrasi negara-negara peserta dan juga institusiinstitusi demokrasi melalui diskusi yang dilakukan antara negara-negara peserta. Selain itu, forum BDF bertujuan untuk mempromosikan pembangunan politik yang dilakukan dengan berdialog dan bertukar pengalaman antarnegara serta menciptakan platform untuk kerjasama dan saling membantu khususnya bidang demokrasi dan pembangunan politik. BDF menggelar pertemuan setiap tahun dan diikuti oleh perwakilan dari negara-negara di kawasan Asia-Pasifik, baik pemimpin pemerintahan, menteri, serta tokoh-tokoh penting (prominent figure), karena BDF bersifat 
inklusif atau terbuka untuk semua negara di kawasan Asia-Pasifik, baik yang telah menganut demokrasi atau yang memiliki cita-cita untuk menjadi lebih demokratis. Forum ini juga memiliki prinsip homegrown democracy, yang berarti demokrasi didasari kepada praktik-praktik nyata nilai-nilai demokrasi oleh negara peserta dengan tidak berpretensi untuk menyalahkan atau membenarkan praktik nyata tersebut. Paling tidak ada dua puluh negara peserta BDF, di mana setiap negara peserta diwakili oleh Menteri Luar Negeri (Menlu). BDF kali pertama dilaksanakan pada 10-11 Desember 2008 dengan mengusung tema Building and Consolidating Democracy: A Strategic Agenda for Asia (Kedutaan Besar Republik Indonesia, 2019).

Pertemuan pertama BDF menetapkan 14 prioritas kerjasama, yaitu meningkatkan dan mengembangkan proses pemilu, memperkuat peran partai politik, supremasi hukum dan memperkuat integritas dan kapasitas lembaga hukum, mempertahankan dan mengembangkan sistem check and balance di antara lembaga pemerintah, meningkatkan dan memperbaiki tata kelola pemerintahan yang baik, akses bagi keterbukaan informasi kepada publik, akses untuk kebutuhan publik, meningkatkan dan memperkuat peran wanita dan kesetaraan gender, menegakkan dan menjamin kebebasan beragama dan toleransi dalam beragama, memperkokoh peran masyarakat sipil/masyarakat madani dan pemuda, mendorong upaya terwujudnya demokrasi, perdamaian dan kehidupan yang harmonis, memperkuat dan mengembangkan peran pers/media massa dalam masyarakat demokratis, meningkatkan penggunaan dan akses teknologi informasi untuk meningkatkan komunikasi dan mendorong demokrasi dan pembangunan di bidang sosial ekonomi (Sekretariat Negara, 2008).

Pelaksanaan BDF yang kedua digelar pada tanggal 10-11 Desember 2009 dengan mengusung tema Promoting Synergy between Democracy and Development in Asia: Prospect for Regional Cooperation (Kementerian Luar Negeri Republik Indonesia, 2009). Selanjutnya BDF dilaksanakan pada 9-10 Desember 2010 dengan mengangkat tema "Democracy and the Promotion of Peace and Stability", diikuti oleh lima puluh dua (52) negara partisipan dari kawasan Asia dan Pasifik. Pertemuan ketiga BDF dihadiri oleh lima belas 
(15) kepala negara dan kepala pemerintahan dan juga 39 negara dan organisasi internasional selaku observers (Ace project, 2010). Selanjutnya forum BDF kembali melakukan pertemuan keempat pada 8-9 Desember 2011, yang bertema 'Enhancing Democratic Participation in a Changing World: Responding to Democratic Voices'. Pada pertemuan keempat ini paling tidak ada delapan puluh (80) negara di kawasan Asia-Pasifik yang ikut berpartisipasi dan dihadiri oleh delapan (8) kepala negara dan kepala pemerintahan (detiknews, 2011). Berdasarkan data yang didapat, dari penyelenggaraan pertemuan pertama BDF sampai dengan pertemuan keempat, peserta yang berpartisipasi dalam pertemuan BDF terus meningkat dari tahun ke tahun. Hal ini membuat BDF semakin nyata sebagai ikon dari promosi nilai-nilai demokrasi di kawasan, pada khususnya kawasan Asia dan Afrika, sebagaimana pernyataan dari Direktur Jenderal (Dirjen) Informasi dan Diplomasi Publik, AM Fachir (detiknews, 2011).

Pada pertemuan keempat BDF tahun 2010 tersebut, dilakukan diskusi antar negara peserta, di mana pada hari pertama dilakukan diskusi dengan tema 'Enhancing Democratic Participation in a Changing World: Responding to Democratic Voices.' Pada hari kedua, dilakukan diskusi yang terbagi menjadi dua sesi, yaitu sesi pertama bertemakan 'The Ability of State to Respond to the Voice of Democracy' dan sesi kedua bertemakan 'Ensuring Democratic Space for Civil Society Participation' Pertemuan selanjutnya BDF, yaitu pertemuan kelima BDF kembali dibuka oleh Presiden Susilo Bambang Yudhoyono pada 8 November 2012. Pertemuan kelima ini dihadiri oleh sepuluh (10) kepala negara dan kepala pemerintahan, pada pertemuan kelima BDF ini pula lah ditetapkan peranan BDF bagi perdamaian dan keamanan untuk mendukung tatanan global (detiknews, 2011). Pertemuan kelima BDF dilaksanakan di Bali International Convention Center (BICC), Hotel Westin, Nusa Dua, Bali dengan tema Advancing Democratic Principles at the Global Setting. Kemudian, pertemuan keenam BDF dilaksanakan pada 7-8 November 2013 dengan mengusung tema Consolidating Democracy in Pluralistic Society (detiknews, 2013). Pada pertemuan keenam ini, BDF mengalami kemajuan yang signifikan. Hal ini terlihat dari negara peserta BDF yang tidak lagi hanya berasal dari kawasan Asia Pasifik, tetapi juga berasal dari Afrika, Asia Tengah 
dan Eropa. Menteri Luar Negeri Indonesia saat itu, Marty Natalegawa, menyatakan negara-negara peserta percaya diri untuk melanjutkan poinpoin relevan hasil dari forum ini (detiknews, 2013).

Pertemuan ketujuh BDF dilaksanakan pada 10-11 Oktober 214, dihadiri oleh tiga kepala negara tetangga, yaitu Presiden Timor Leste Xanana Gusmao, Presiden Filipina Benigno Aquino dan Sultan Brunei Darussalam Hassanal Bolkiah (Medcom, 2014). BDF VII dihadiri oleh 85 negara yang tidak hanya dari kawasan Asia Pasifik, tetapi juga beberapa negara dari kawasan berbeda serta lima organisasi internasional (suara.com, 2014). Tema BDF VII adalah Evolving Regional Democratic Architecture, dimana tema ini mencerminkan optimisme bersama bahwa pembangunan demokrasi sejatinya terus bertumbuh di kawasan Asia Pasifik, baik dalam konteks pembangunan demokrasi di tataran domestik maupun dalam lingkung organisasi-organisasi kerjasama di regional, sebagaimana disampaikan Teuku Faizasyah, Staf Khusus Presiden Bidang Hubungan Internasional (Republika.co.id, 2014). Meskipun perhelatan BDF VII ditandai dengan aksi protes dari lembaga swadaya masyarakat di Indonesia, tetapi BDF VII tetap dilaksanakan (Beritasatu.com, 2014).

Pertemuan kedelapan BDF dilakukan di Nusa Dua, Bali pada 10-11 Desember 2015 dan diikuti oleh perwakilan menteri dan wakil menteri dari 79 negara dan 3 organisasi internasional dengan mengusung tema "Democracy and Effective Public Governance". Tema ini diharapkan akan menjadi agenda bagi negara yang menghadiri pertemuan VIII BDF, yaitu penerapan demokrasi dan tata kelola pemerintahan yang efektif akan mampu mendorong pembangunan yang komprehensif dan holistik dengan pendekatan yang mengutamakan transparansi, akuntabilitas, partisipasi dan penegakan hukum (Kabar24, 2015). Selanjutnya, pertemuan kesembilan BDF digelar pada 8-9 Desember 2016 dengan mengetengahkan tema Religion, Democracy and Pluralism, maka sesuai dengan tema tersebut, para peserta juga akan diajak untuk melihat bagaimana kerukunan antar umat beragama di Bali (Metrobali, 2016).

Pertemuan kesembilan BDF ini diikuti oleh 58 menteri luar negeri dari negara-negara di kawasan Asia Pasifik dan 67 peninjau dari organisasi 
internasional yang berasal dari delapan negara (Metrobali, 2016). Pertemuan kesepuluh Bali Democracy Forum dianggap membawa sejarah tersendiri, karena sejak pertemuan pertama BDF sampai dengan pertemuan kesembilan BDF dilaksanakan dengan bertempat di Bali. Pertemuan kesepuluh BDF dilakukan di Indonesia Convention Exhibition (ICE) Serpong, Tangerang, Banten (Kompas.com, 2017) terkait terjadinya aktivitas vulkanik Gunung Agung, Bali (Liputan6, 2017). Selain itu, pertemuan kesepuluh BDF bertepatan dengan penetapan Yerusalem sebagai ibu kota Israel yang dinyatakan oleh Presiden Donald Trump (Amerika Serikat), sehingga forum ini digunakan oleh Indonesia untuk menyuarakan pendapat/posisi Indonesia terkait hal tersebut melalui pidato yang disampaikan oleh Menlu RI Retno Marsudirini dan juga untuk melakukan diplomasi dengan berbagai negara yang hadir, seperti Qatar dan Tunisia serta negara-negara Arab atau negaranegara dari kawasan Timur Tengah (Liputan6, 2017).

Tema dalam pertemuan BDF kesepuluh adalah "Does Democracy Deliver?" dan diikuti oleh 103 delegasi termasuk tujuh delegasi dari organisasi internasional (Okenews, 2017). Perbedaan pertemuan kesepuluh BDF dengan pertemuan-pertemuan BDF lainnya adalah adanya sesi debat yang memungkinkan para Menlu aktif dan situasi yang interaktif, menggelar student conference, untuk mempromosikan demokrasi di generasi muda yang dilaksanakan terlebih dulu pada 5-6 Desember 2017 diikuti oleh 160 pelajar dan mahasiswa, dan juga dilaksanakan BDF Chapter Tunis yang dilaksanakan di Tunisia pada bulan Oktober sebagai pendahuluan (Liputan6, 2017). Pertemuan kesebelas BDF dilaksanakan di Nusa Dua, Bali pada 6-7 Desember 2018 dengan mengusung tema Democracy for Prosperity. BDF kali ini dihadiri oleh 500 anggota delegasi dari 91 negara dan tujuh organisasi internasional sebagai peninjau (Antaranews.com, 2018).

Pertemuan kedua belas BDF digelar di Bali Nusa Dua Convention Center (BNDCC), Bali pada 5-6 Desember 2019 dan mengusung tema Democracy and Inclusivity dengan dihadiri oleh 90 perwakilan negara dan tujuh perwakilan organisasi internasional (Kementerian Luar Negeri Indonesia, 2019). Pertemuan kedua belas BDF juga memfokuskan pembahasan pada pemberdayaan peran perempuan dengan dilakukannya Ministerial Panel 
yang bertajuk "Women Leadership, Inclusion and State of Democracy" MenluMenlu perempuan yang berasal dari Australia, Indonesia, Kenya dan Namibia akan berbagi mengenai praktik mengenai partisipasi perempuan di politik, penyusunan kebijakan publik dan aspek lainnya (Kementerian Luar Negeri Indonesia, 2019).

Pertemuan pertama BDF sampai dengan pertemuan kedua belas BDF yang dilaksanakan pada tahun lalu dapat terlihat bahwa forum BDF merupakan forum yang efektif dalam mendiskusikan berbagai tema di dalam sebuah tema besar demokrasi. Hal ini dapat terlihat dari semakin meningkatnya jumlah negara dari tahun ke tahun yang mengikuti pertemuan BDF. Selain jumlah peserta yang meningkat, delegasi yang pada awalnya berasal dari Asia-Pasifik, dalam perkembangan pertemuan BDF selanjutnya semakin meluas dengan ikutnya berbagai negara dari kawasan-kawasan berbeda. Hal ini menunjukkan BDF telah menjadi fokus perhatian bagi negara-negara untuk semakin meningkatkan kapasitas negaranya dalam mengimplementasikan praktik demokrasi di negaranya masing-masing. BDF juga telah berhasil menjadi forum pertemuan yang diperhitungkan, tidak hanya di tataran regional, tetapi juga di tataran global.

\section{Strategi Diplomasi Publik Indonesia melalui Bali Democracy Forum}

Bali Democracy Forum merupakan forum multilateral yang bersifat inklusif dan terbuka yang digagas oleh Indonesia di bawah pemerintahan Presiden Susilo Bambang Yudhoyono (SBY) dan dilaksanakan setiap tahun sejak Desember 2008 sampai dengan pertemuan terakhirnya pada tahun lalu sebelum pandemi COVID-19 di Nusa Dua, Bali pada Desember 2019. Setiap pertemuan BDF selalu mengemukakan tema yang terkait erat dengan nilainilai demokrasi. Hal ini menjadi fokus bagi negara-negara peserta karena setiap negara peserta ingin terus meningkatkan kapasitas institusi di negaranya menjadi demokratis. BDF bertujuan untuk mempromosikan nilainilai demokrasi dan memajukan demokrasi di kawasan Asia Pasifik, meskipun pada perkembangannya, BDF mengalami perluasan kawasan dengan ikut sertanya berbagai negara dari kawasan di luar Asia Pasifik. 
Dalam pelaksanaan diplomasi publik, diplomasi publik memerlukan strategi agar dapat menentukan arah pelaksanaannya. Diplomasi publik dipakai sebagai pelengkap terhadap berbagai upaya-upaya yang dilakukan oleh pemerintah agar dapat mengoptimalkan aktivitas komunikasi, yaitu dengan cara mengumpulkan, mengolah dan menyebarluaskan informasi demi kepentingan nasional sebuah negara. Indonesia melalui pelaksanaan Bali Democracy Forum telah berhasil memperlihatkan kepada masyarakat internasional bahwa pemerintah Indonesia dapat mengajak dan mengumpulkan negara-negara untuk hadir dalam pertemuan-pertemuan BDF untuk dapat saling berbagi pengalaman mengenai proses demokrasi di setiap negara, baik di kawasan Asia Pasifik maupun di negara-negara di luar kawasan Asia Pasifik.

Dalam perjalanan BDF sejak pertemuan pertama, telah membawa banyak pengaruh positif, diantaranya dengan dibentuknya Institute for Peace and Democracy (IPD) yang telah diresmikan bersamaan dengan pertemuan pertama Bali Democracy Forum pada tahun 2008 untuk mengembangkan demokrasi. Institute for Peace and Democracy adalah institusi internasional yang beranggotakan negara-negara di Asia Pasifik untuk dapat memberikan kontribusi dalam pengembangan dan promosi demokrasi. Tujuan Institute of Peace and Democracy diantaranya untuk memberikan dukungan substansi akademis dan teknis bagi dialog yang dilakukan di setiap pertemuan Bali Democracy Forum, mengelola dan mengorganisasi kegiatan regular Bali Democracy Forum dan bertindak sebagai lembaga yang mengimplementasikan agenda Bali Democracy Forum, juga untuk menjadi pusat studi dan pengetahuan tentang demokrasi dan perdamaian, serta untuk mendorong pengembangan dan promosi demokrasi di kawasan Asia Pasifik.

BDF juga membentuk Bali Democracy Student Conference dan Bali Civil Society and Media Forum untuk dapat menyebarluaskan pemahaman demokrasi dengan menetapkan sasaran diplomasi publik kepada masyarakat luas, terutama generasi muda dan juga media. Dari pembentukan kedua forum tersebut, strategi diplomasi publik Indonesia adalah dengan melakukan promosi BDF dan tentu saja promosi demokrasi kepada 
masyarakat luas, tidak hanya di kalangan elit pemerintahan saja, tetapi juga kepada masyarakat, generasi muda dan tentu saja media massa, di mana strategi ini berjalan dengan efektif. Media adalah sumber berita, sehingga media harus dijaga kenetralan dan independensinya. Pada saat ini, media sosial telah marak penggunaannya dalam masyarakat, bahkan melalui media sosial juga masyarakat dapat ikut serta dan berpartisipasi aktif dalam menyuarakan aspirasinya dan ini tidak langsung adalah bagian kegiatan demokrasi itu sendiri. Melalui BDF juga banyak negara terus mempromosikan dan mempraktikkan demokrasi di negaranya masingmasing. Sebagai contoh Myanmar, Fiji dan Kamboja.

BDF sebagai strategi diplomasi publik Indonesia berhasil semakin memperlihatkan citra positif Indonesia sebagai negara yang menerapkan nilai-nilai demokratis. BDF disertai dengan pembentukkan IPD, Bali Democracy Student Conference dan Bali Civil Society and Media Forum mampu memperlihatkan kapasitas Indonesia sebagai sebuah negara demokrasi yang terus mempromosikan, mempraktikan dan menyebarluaskan nilai-nilai demokrasi di negara-negara dalam tataran regional dan global dengan mengajak seluruh komponen masyarakat sipil, media dan pelajar serta mahasiswa.

\section{KESIMPULAN}

Bali Democracy Forum telah menjadi strategi diplomasi publik yang berhasil bagi Indonesia dalam meningkatkan citra positif di kawasan Asia Pasifik bahkan ke tingkat global sebagai negara yang demokratis dengan rutin melakukan pertemuan BDF setiap tahun sejak pertemuan pertama BDF pada 2008. Pertemuan BDF sendiri merupakan pertemuan yang efektif dan terus menjadi perhatian internasional ditandai dengan semakin meningkatnya negara yang ikut serta dan semakin meluasnya negara yang ikut serta yang tidak hanya berasal dari kawasan Asia Pasifik, tetapi juga berasal dari kawasan lain di luar Asia Pasifik, seperti negara dari kawasan Timur Tengah dan Afrika. Strategi diplomasi publik Indonesia melalui BDF dibangun dengan sinergi pemerintahan atau negara-negara dengan masyarakat sipil, media dan generasi muda yaitu pelajar dan mahasiswa. 


\section{DAFTAR PUSTAKA}

Ace Project. (2010). Bali Democracy III (2010). Diakses pada: 27 Oktober 2020, http://aceproject.org/regions-en/countries-andterritories/ID/events/bali-democracy-forum-iii-2010

Andrlic, Mladenn. \& Gustovic-Eregovac, Andrea. (2012). ed. Diplomatic Academy Proceeding 13th CEI Dubrounik Diplomatic Forum 2001. ISSN 1334-7659 Vol. 9 No. 1, 2012. Diplomatic Academy Ministry of Foreign and European Affairs Republic of Croatia.

Antaranews.com. (5 Desember 2018). Indonesia Selenggarakan Bali Democracy Forum ke-11. Diakses pada: 30 Oktober 2020, https://www.antaranews.com/berita/774809/indonesiaselenggarakan-bali-democracy-forum-ke-11

Beritasatu.com. (7 Oktober 2014). Bali Democracy Forum Disinyalir Hanya Pesta Seremonial SBY. Diakses pada: 29 Oktober 2020, https://www.beritasatu.com/yudo-dahono/nasional/215699/balidemocracy-forum-disinyalir-hanya-pesta-seremonial-sby

Creswell, John W. (2010). Design: Pendekatan Kualitatif, Kuantitatif dan Campuran. Yogyakarta: Pustaka Pelajar

Detiknews. (7 Desember 2011). Bali Democracy Forum IV akan digelar Awal Desember 2011. Diakses pada: 27 Oktober 2020, https://news.detik.com/berita/d-1784816/bali-democracy-forum-ivakan-digelar-awal-desember-2011

Detiknews. (8 November 2013). Bali Democracy Forum VI Berakhir, Bagaimana Selanjutnya?. Diakses melalui: https://news.detik.com/berita/d$\underline{\text { 2407976/bali-democracy-forum-vi-berakhir-bagaimana-selanjutnya }}$

Dugis, Vinsensio. (2016). Teori Hubungan Internasional Perspektif-Perspektif Klasik. Surabaya: Cakra Studi Global Strategis. 
Esposito, John L. (1986). Islam dan Politik. Jakarta: Bulan Bintang.

H, Hadari Nawawi. (1996). Penelitian Terapan. Yogyakarta: Gajahmada University Press.

Jackson, Robert. \& Sorensen, Georg. (1999). Introduction to International Relations. United Kingdom: Oxford University.

K, Septiawan Santana. (2007). Menulis Ilmiah Metodologi Penelitian Kualitatif. Jakarta: Yayasan Pustaka Obor Indonesia.

Kedutaan Besar Republik Indonesia di Amman, Kerajaan Yordania Hasyimiah. (4 Oktober 2019). Bali Democracy Forum. Diakses pada: 27 Oktober 2020, https://kemlu.go.id/amman/id/news/2595/balidemocracy-forum

Kementerian Luar Negeri Indonesia. (5 Desember 2019). Merangkul Demokrasi Inklusif, Menlu Retno Buka Bali Democracy Forum ke-12. Diakses pada: 5 Desember 2019, 30 Oktober 2020, https://kemlu.go.id/portal/id/read/854/berita/merangkul-demokrasiinklusif-menlu-retno-buka-bali-democracy-forum-ke12

Kementerian Luar Negeri Republik Indonesia. (2009). Phocagaller of BDF. Diakses $\quad 27 \quad$ oktober 2020, https:/ / bdf.kemlu.go.id/component/phocagallery/4-bdf-ii/detail/90$\underline{\text { bdf-ii-2?tmpl=component\&phocaslideshow=0\&Itemid }=1}$

Kompas.com. (7 Desember 2017). Buka Bali Democracy Forum ke-10 Ini Pesan Jusuf Kalla. Diakses pada: 30 Oktober 2020, https://nasional.kompas.com/read/2017/12/07/12150871/bukabali-democracy-forum-ke-10-ini-pesan-jusuf-kalla?page=all

Leonard, Mark. (2002). Public Diplomacy. London: The Foreign Policy Center.

Liputan6. (8 Desember 2017). Bali Democracy Forum Kesepuluh yang Bersejarah Resmi Ditutup. Diakses pada: 30 Oktober 2020, 
https://www.liputan6.com/global/read/3188502/bali-democracyforum-ke-10-yang-bersejarah-resmi-ditutup

Mcw.com. (7 Desember 2018). Bali Democracy Forum ke 11 Tahun 2018 Hari Pertama Berlangsung Aman. Diakses pada: 30 Oktober 2020, https://www.mcwnews.com/read/2018/12/07/3095/bali-democracyforum-ke-11-tahun-2018-hari-pertama-berlangsung-aman.html

Medcom.id. (10 Oktober 2014). SBY Buka Bali Democracy Forum VII. Diakses pada: 29 Oktober 2020, https://video.medcom.id/metronews/VNxB2Wyk-sby-buka-bali-democracy-forum-vii

Melissen, Jan. (2005). The New Public Diplomacy, New York: Palgrave Macmillan.

Metrobali. (3 Oktober 2016). Bali Democracy Forum ke- 9 Digelar 8 Desember 2016 di Nusa Dua. Diakses pada: 30 Oktober 2020, http:/ / metrobali.com/bali-democracy-forum-ke-9-digelar-8-desember2016-di-nusa-dua/

Moleong, Lexy J. (2007). Metodologi Penelitian Kualitatif. Bandung: PT. Remaja Rosdakarya Bandung.

Nugroho, Heru. (2012). Demokrasi dan Demokratisasi: Sebuah Kerangka Konseptual untuk Memahami Dinamika Sosial Politik di Indonesia, Jurnal Pemikiran Sosiologi Volume 1 Nomor 1 Tahun 2012.

Okenews. (7 Desember 2017). Diikuti 103 Delegasi, BDFX 2017 Resmi Dibuka. Diakses pada: 30 Oktober 2020, https://news.okezone.com/read/2017/12/07/18/1826505/diikuti103-delegasi-bdf-x-2017-resmi-dibuka

Rachmawati, Iva. (2016). Diplomasi Publik Meretas Jalan bagi Harmoni dalam Hubungan Antarnegara. Jakarta: Calpulis.

Republika.co.id. (9 Oktober 2014). SBY Akan Hadiri Bali Democracy Forum. Diakses pada: 29 Oktober 2020, 
https://nasional.republika.co.id/berita/nasional/umum/nd6eni/sbyakan-hadiri-bali-democracy-forum

Rosadi, Doddy. (10 Oktober 2014). Kemlu: Bali Democracy Forum untuk Kembangkan Demokrasi. Diakses pada: 29 Oktober 2020, https://www.suara.com/news/2014/10/10/093736/kemlu-balidemocracy-forum-penting-untuk-kembangkan-demokrasi

Sekretariat Negara. (2008) Bali Democracy Forum. Diakses pada: 29 Oktober 2020, www.setneg.go.id.

Sitorus, Ropesta. (7 Desember 2015). Bali Democracy Forum VIII digelar 10-11 Desember 2015. Diakses pada: 7 Desember 2015, 29 Oktober 2020, https://kabar24.bisnis.com/read/20151207/19/499379/balidemocracy-forum-viii-digelar-10-11-desember-2015

Steans, Jill. \& Pettiford, Lloyd. (2001). International Relations Perspectives and Themes. Essex: Pearson Education Limited.

Sugiyono. (2011). Metode Penelitian Kuantitatif dan Kualitatif dan R\&D. Bandung: Alfabeta.

Ubaedillah, A. \& Rozak, Abdul. (2006). Pendidikan Kewarganegaraan: Demokrasi, Hak Asasi Manusia dan Masyarakat Madani. Jakarta: ICCE UIN Syarif Hidayatullah. 
